\title{
A teorija vremena i početak svemira
}

\author{
Valentin Stuhne*, Dalibor Renić***
}

\begin{abstract}
Sažetak
Pitanje vremenske ontologije u vezi s početkom svemira ključno je u filozofiji za neke kozmološke argumente za Božju opstojnost (napose za kalām kozmološki argument), ali je zanimljivo i samo po sebi. Ovaj članak brani poziciju da je početak svemira opravdano interpretirati u A teorijskoj ontologiji, nasuprot alternativnoj B teoriji. Dva najjača prigovora A teoriji su problem istinitosti sudova o prošlosti i budućnosti te problem nekompatibilnosti sa specijalnom teorijom relativnosti. Argumentiramo da je prvi prigovor riješen kad A teoretičar nađe prikladan podmet za instancijaciju temporalnih svojstava. Na drugi prigovor odgovaramo da A teorija nije nekompatibilna sa specijalnom teorijom relativnosti simpliciter, nego je nekompatibilna s Minkowskijevom interpretacijom te teorije. Predlažemo nekoliko načina kako se može zaobići ta interpretacija.

Ključne riječi: filozofija vremena, početak svemira, kozmološki argument, standardni kozmološki model, A teorija vremena, B teorija vremena
\end{abstract}

\section{Uvod}

Pitanje početka svemira zanimljivo je pod više vidika. U filozofiji se redovito povezuje s dokazima za Božju opstojnost, osobito s tzv. kalām kozmološkim argumentom. Taj argument ima bogatu povijest. Njegove elemente nalazimo u nastojanju kršćanskih teologa da opovrgnu aristotelovsko učenje o vječnosti svemira. Argument su dalje razvili islamski filozofi, u kontekstu racionalne obrane religijskog vjerovanja koju su nazivali kalām. Kalām argument je jednostavan, a njegov najpoznatiji suvremeni branitelj William L. Craig tipično ga izlaže u ovoj formulaciji: (1) sve što je počelo postojati ima uzrok; (2) svemir je počeo postojati; (3) dakle, svemir ima uzrok (Craig i Sinclair, 2009, 101-102). Prva premisa predstavlja jednu od klasičnih metafizičkih formulacija kauzalnog načela. To je načelo kroz povijest doživjelo brojne kritike, ali je manje problematično u kon-

* Valentin Stuhne, mag. phil., Katolički teološki fakultet, Sveučilište Innsbruck. Adresa: KarlRahner-Platz 1, 6020 Innsbruck, Austrija. E-pošta: valentin.stuhne@student.uibk.ac.at

** Doc. dr. sc. Dalibor Renić, Fakultet Filozofije i religijskih znanosti, Sveučilište u Zagrebu. Adresa: Jordanovac 110, 10000 Zagreb, Hrvatska. E-pošta: drenic@ffrz.hr 
tekstu suvremenih rasprava, jer prirodoznanstveni kontekst tih rasprava uglavnom pretpostavlja metafizički i epistemički realizam. Daleko je kontroverznija druga premisa.

Craig razlikuje dvije strategije, apriornu i aposteriornu, za opravdanje tvrdnje da je svemir počeo postojati. Apriorna brani metafizičku nemogućnost beskonačnog temporalnog regresa, odnosno aktualne beskonačnosti, služeći se spoznajama transfinitne aritmetike. Aposteriorna strategija oslanja se na standardni kozmološki model velikog praska i implikacije drugog zakona termodinamike. Iako je moderna znanost vjerojatno najjači razlog prihvaćanja druge premise, postoje i prigovori istoj premisi koji proizlaze barem dijelom i iz suvremene znanosti. Naime, ideja dinamičkog početka svemira uvjetovana je istinitošću A teorije vremena. Prema konkurentskoj B teorijskoj ontologiji proizlazi da je irelevantno govoriti o prezentističkom vremenskom početku svemira. Početak postojanja je dinamički koncept koji pretpostavlja neku vrstu A teorijske ontologije, a u B teorijskoj ontologiji ne možemo, striktno govoreći, tvrditi da je svemir počeo postojati: svemir je samo jedan prostornovremenski blok, s jedne strane omeđen singularnosti. Tu singularnost B teoretičari isto znaju nazivati početkom svemira, ali svemir počinje singularnosti na sličan način kao što plaža započinje prvim zrnom pijeska. Nije riječ o početku postojanja u striktnom smislu, nego u krajnje reduciranom smislu. U A teorijskoj ontologiji vrijedi u punom smislu govoriti o kauzalnosti, realnom vremenskom prolasku i vezanim ontološkim načelima kao što je primjerice ex nihilo nihil fit — a to daje jaku potporu kozmološkim argumentima. Nasuprot tomu B teorija bitno je eternalistička: vremenski prolazak ne postoji, a kauzalnost je svedena na problematične B relacije ili je uopće nema.

Iako će pojam početka postojanja svemira ukratko biti kontekstualiziran u prirodoznanstvenom okviru, cilj je ovoga rada usredotočiti se upravo na obranu tvrdnje da se početak svemira s pravom može interpretirati A vremenskom ontologijom. Stoga, nećemo se posebno fokusirati na obranu standardnog kozmološkog modela, nego ćemo odgovoriti na istaknute izazove metafizike vremena u odnosu na standardni kozmološki model. Problem je u svojoj biti interpretacijski jer ista fizikalna teorija može imati više (međusobno isključivih ili uključivih) ontoloških pretpostavki ili modela. Teorija velikog praska nije izuzetak: hoće li početak svemira biti interpretiran A teorijski ili B teorijski nije više pitanje te same teorije, nego ovisi o širim znanstvenim i filozofskim kozmološkim razmatranjima. Dva glavna prigovora A teoriji vremena su problem istinitosti prošlih i budućih sudova te problem nekompatibilnosti sa specijalnom teorijom relativnosti. Upravo na ta dva prigovora namjeravamo odgovoriti, nadovezujući se na Craigovo filozofsko promišljanje o početku svemira i nadopunjujući njegovo argumentiranje. Nemamo pretenziju da ćemo prigovore jednom za svagda potisnuti - rasprava se tako i tako vodi na induktivnoj razini mišljenja — ali barem ćemo upozoriti na njihove probleme i pokušati umanjiti im snagu. 


\section{Prirodoznanstveno utemeljenje teze o početku svemira}

U suvremenoj je fizikalnoj kozmologiji široko prihvaćen stav da je svemir počeo postojati prije oko 13,5 milijardi godina i to događajem ${ }^{1}$ koji se naziva veliki prasak (Big Bang). Najuspješnijim kozmološkim modelom u znanstvenom svijetu danas se smatra standardni kozmološki model, koji ima jaku potporu u detektiranom pozadinskom mikrovalnom zračenju i nukleosintezama lakih elemenata (Petković, 2006, 151). Standardni model nastao je revolucijama u kozmologiji kroz zadnjih stotinjak godina. Prije tog razdoblja istaknuti model bio je model vječnog svemira (Craig i Sinclair, 2009, 125).

Model širećeg svemira neovisno su donijeli A. Friedmann i G. Lemaître, a važna potvrda adekvatnosti njihova modela došla je otkrićem spomenutog pozadinskog mikrovalnog zračenja od A. Penziasa i R. W. Wilsona 1965. godine. To zračenje lako je objasniti u modelu velikog praska, jer se prikazuje kao ostatak početnog elektromagnetnog zračenja koje je širenjem i hlađenjem svemira svedeno u mikrovalnu regiju elektromagnetskog spektra (Liddle, 2003, 75-78).

Prema Fridemann-Lemaître modelu, s vremenom se povećavaju udaljenosti između idealnih čestica i kozmološkog fluida, stoga nas vraćanje unatrag vremenskom linijom dovodi do sve veće gustoće. Tako se primičemo do inicijalne singularnosti u kojoj se otkriva infinitezimalna zakrivljenost prostor-vremena, te maksimalna gustoća i temperatura pojavnog svemira. Taj model ne opisuje događaje u samoj singularnosti ili $\mathrm{u} \mathrm{t}_{0}$ nastanka svemira, jer u Planckovoj eri nisu vrijedili fizikalni zakoni kvantne fizike i teorije relativnosti, stoga se sva daljnja fizikalna objašnjenja tu prekidaju (Craig i Sinclair, 2009, 129; Paar, 2011, 29).

Ključni je opservacijski dokaz hipoteze dinamičkog svemira kozmički crveni pomak koji nastaje kad se izvor elektromagnetnog zračenja udaljava od opažača, zapravo Dopplerov efekt. Slično kao što se frekvencija policijske sirene mijenja relativno o poziciji izvora zvuka i receptora zvuka, tako uočavamo da se svjetlost svih galaksija koje možemo uočiti pomiče prema crvenom dijelu spektra. Pomicanje prema crvenom dijelu spektra objašnjeno je udaljavanjem izvora svjetlosti od nas prema Dopplerovom efektu. E. Hubble je 1929. uočio da taj crveni pomak nije nasumičan, nego je proporcionalan udaljenosti galaksije od nas: što je dalje neka galaksija, to se brže od nas odmiče. To odmicanje ne može se događati ako je svemir statičan (Hawking, 2007, 27).

U nešto novije vrijeme, S. Hawking i R. Penrose objelodanili su teoreme koji demonstriraju da, ako vrijedi opća teorija relativnosti (uz neke tehničke izuzetke), prošlost našeg svemira mora uključivati singularnost (Craig i Sinclair, 2009, 131). U sasvim modernom kontekstu, iako je standardni model velikog praska

1 Kao što ističe Reichenbach, može biti problematično veliki prasak nazivati događajem: »Događaj se odvija unutar prostornovremenskog konteksta. Ali, veliki prasak nema prostornovremenskog konteksta: nema ni vremena prije velikog praska niti prostora u kojemu se veliki prasak odvio « (Reichenbach, 2016, s. v. The Big Bang is Not an Event). Da bismo izbjegli takve prigovore, pod događajem tu mislimo na instancijaciju ili pojavak. (Napominjemo da su citate sa stranih jezika preveli autori.članka) 
prihvaćen, pojavili su se različiti alternativni modeli koji na neki način zaobilaze Hawking-Penrose teoreme, primjerice, model vječne inflacije; model cikličkog svemira i model emergentnog svemira. Fizičari A. Mithani i A. Vilenkin 2012. prikazali su jasne nedostatke tih novijih alternativnih modela i zaključili da ni jedan od tih modela ne može biti vječan u prošlosti (Mithani i Vilenkin, 2011, 1-5). Valja spomenuti da su 2003. A. Borde, A. W. Guth i A. Vilenkin utvrdili širi teorem singularnosti od Hawkinga i Penrosea, koji utvrđuje da bilo koji svemir koji se u prosjeku širi mora imati granicu u konačnoj prošlosti (Borde i dr., 2003, 1-4; Craig i Sinclair, 2009, 142). Ti dokazi čine uvriježeni kozmološki model opravdanim i daju nam razloge za prihvaćanje tvrdnje da svemir ima početak, što je dovoljno opravdanje za odbacivanje alternativnih modela i koncepcije vječnog svemira.

Usprkos tomu, uvriježeni model otvoren je za radikalno različite vremenske ontologije, početak svemira može biti interpretiran kao dinamičan početak postojanja, ali može i izbjegavati metafiziku nastajanja i obvezati se za reduktivističke B termine. Upravo se tu pojavljuju nevolje tumačenja: kad je riječ o matematičkom formalizmu kozmološke teorije, o svemiru uglavnom možemo raspravljati ontološki neutralno, no, svako tumačenje matematičkog formalizma jedne fizikalne teorije u biti zahtijeva ontološke obveze.

\section{Početak svemira i filozofija vremena}

\subsection{A i B teorije vremena}

Naveli smo ranije da tvrdnja o dinamičkom početku svemira stoji i smislena je uz pretpostavku A teorije vremena. Kako bi se odvagnulo je li A teorija vremena vjerojatna nasuprot B teoriji, moramo prvo istražiti što su to A i B teorije vremena i koji ih razlozi podupiru.

Razliku između A i B vremenskih nizova prema kojima su nastale A i B teorije vremena uveo je J. E. McTaggart u poznatom članku The Unreality of Time (McTaggart, 1908). McTaggart je smatrao da nam se vrijeme, prima facie, otkriva u dva niza: A i B. A niz tiče se prošlosti, sadašnjosti i budućnosti, a B se sastoji od relacija prije, istovremeno sa, i nakon. Riječi koje označavaju A i B nizove naziva vremenskim odrednicama ili determinacijama. Distinkcija u A nizu je promjenjiva, a distinkcija u B nizu nepromjenjiva. U jedno doba Aristotel je bio budući, u drugo je živio u sadašnjosti, a sada je njegov život stvar prošlosti. Tomu usprkos, uvijek će vrijediti da je Aristotel živio prije Napoleona, ta relacija nije podložna promjeni. Za McTaggarta oba su niza potrebna kako bismo dobili vrijeme, s tim da je A niz fundamentalniji od B niza. Ako imamo samo A niz ili samo B niz, prema njegovom pogledu, ne dobivamo vrijeme. Međutim, kad interpretiramo vrijeme kao rezultat tih dvaju nizova, dobivamo poznati McTaggartov paradoks, koji nas vodi do zaključka iluzornosti vremena.

Inspirirani McTaggartom, filozofi vremena nisu bili uvjereni u iluzornost vremena, nego su se podijelili na dvije temeljne skupine: A teoretičare i B 
teoretičare. Ta je podjela nastala, između ostalog, s obzirom na opću strategiju rješavanja McTaggartovog paradoksa, jer su A teoretičari smatrali da je A niz dovoljan za vrijeme, a B teoretičari su isto tvrdili za B niz. Dobar primjer obrane A teorije vremena od paradoksa je iznio Craig:

»Iako je McTaggart preferirao pogled da su A determinacije relacije radije negoli kvalitete, njegova analiza vremenskog postojanja tretira ih kao kvalitativnu promjenu, barem dok pokušava kombinirati B teoretičarsku ontologiju s A teoretičarskim postajanjem. Na čistoj A teoretskoj ontologiji, jedini vremenski objekti koji postoje su oni koji postoje u sadašnjem stanju. Drugim riječima, čista A teorija povlači metafiziku prezentizma. U prezentističkoj ontologiji, prošlost i budućnost događaja/ objekta/vremena nisu realni ili postojeći i, dakle, ne pokazuju svojstva poput prošlosti ili budućnosti. Stoga, ne može biti pitanja oko razmjene budućnosti za sadašnjost nekog entiteta ili prodaje sadašnjosti za prošlost. Entiteti dolaze i prolaze apsolutno, tako da su jedini temporalni entiteti sadašnji entiteti. Dakle, izvor McTaggartova paradoksa ne leži u A nizu, nego u McTaggartovom neobičnom braku između A i B niza.« (Craig, 2000, 179)

S druge strane, B teoretičari nastoje dati razloge zašto je B niz dovoljan i pronaći načine kako da reduciramo A niz na B niz, ili da A niz proglasimo irelevantnim za vrijeme. Svoje poglede uglavnom nastoje obraniti suvremenom fizikom jer se čini kao da pogled na vrijeme specijalne teorije relativnosti neizbježno vodi do $\mathrm{B}$ teoretske ontologije. Dobar primjer B teoretičara koji A niz proglašava irelevantnim je J. J. C. Smart (Mozersky, 2013, 169). Razlog je taj što A niz pretpostavlja nešto kao protok vremena, a protok pretpostavlja nešto kao mjeru tog protoka. Naime, sve što na neki način teče, očito to čini nekom mjerom. Mjera protoka mora biti dovedena uzevši u obzir nešto drugo, tako da nam treba druga temporalna dimenzija i tako ad infinitum. Zato je, prema Smartu, potpuno promašeno govoriti o vremenu kao nekoj dinamičkoj stvarnosti.

Osim tih dviju načelnih podjela, postoje teorije koje objedinjavaju različite aspekte A i B teorija vremena. C. D. Broad je osmislio teoriju zvanu „rastući blok“, koja je dobar primjer takve, hibridne, teorije. Bit je sadašnjeg događaja da doslovno ničemu ne prethodi, a ništa drugo se nije dogodilo sadašnjemu događaju da postane prošli, osim dodavanja novih slojeva egzistencije cjelokupnoj povijesti svijeta (Bigelow, 2013, 153). To je teorija koja opet podrazumijeva nekakvo pomicanje, barem tih slojeva egzistencije, pa nije čista B teorija.

Sukob između A i B teorije često je u širem smislu prikazan kao prikaz dvije vremenske ontologije, prezentizma i eternalizma, iako filozofi vremena tipično priznaju različite verzije A i B teorije koje ne spadaju striktno pod te ontologije (Zimmerman, 2008, 2013). Ned Markosian prezentizam definira kao pogled prema kojemu je uvijek nužno istina da samo sadašnji objekti postoje (Markosian, 2014, s. v. Presentism, Eternalism, and The Growing Universe Theory). Markosianova se definicija ipak dade proširiti. Ne smijemo zanemariti postojanje sadašnjih relacija, događaja i svojstava. Moramo spomenuti i ono što K. Miller ističe kao dinamičku tezu: sadašnjost je promjenjiva, koji trenutak biva sadašnjim jest promjenjivo (Miller, 2013, 346). Uz to, objekti u prezentizmu počinju i prestaju postojati apsolutno, kao što smo vidjeli ranije iz Craigove kritike McTaggartova 
paradoksa. Eternalizam je u općem smislu negacija prezentizma. Nije slučaj da samo sadašnji objekti postoje. Postoje sadašnji, ali i prošli i budući, samo na drugoj poziciji vremenske linije, vrlo slično kao što postoje Jakarta i Helsinki, samo na drugom mjestu. Tomu je tako jer eternalist ne vjeruje u postojanje pravih vremenskih svojstava kao „biti budući ili prošli“, nego samo u vremenske relacije. Koji je trenutak sadašnji trenutak nije promjenjivo, a objekti ne počinju i ne prestaju postojati; oni postoje u relacijama s drugim objektima koji isto tako postoje. Jasnije se to može predočiti kad bismo zamislili da je svijet zapravo četverodimenzionalni blok prostor-vremena u kojem su objekti u dvomjesnim relacijama ranije od, istovremeno sa, i nakon. Što se tiče implikacija A i B teorije u kozmologiji, A teorija implicira da je početak svemira događanje, realna temporalna aktualizacija koja je trenutačno nepostojeća. Početci postojanja intuitivno zahtijevaju kauzalna objašnjenja, jer postajanje spada pod kauzalno načelo. B teorija implicira bezvremeno postojanje svemira u kojem su događaji u relaciji ontološke jednakosti. Nema govora o postajanju, realnom prolasku vremena ili vremenskom nastajanju. U skladu s time, zahtjev za kauzalnim objašnjenjem gubi svoju intuitivnost, a klasično kauzalno načelo gubi relevantnost. To ne znači da svemir kao totalnost nema dovoljan razlog: još uvijek možemo pričati o uspješnom leibnizovskom argumentu u slučaju B teorije vremena. ${ }^{2}$ No, kalām argument, u Craigovoj formulaciji, zahtijeva klasično kauzalno načelo, a time i njegove A teorijske korijene.

\subsection{Odrednice A teorije}

Uzmimo primjer Deana Zimmermana kako bismo demonstrirali jedan oblik pogleda na A teoriju vremena. Zimmerman postavlja dva temeljna pitanja koja prema njemu ocrtavaju bit ontoloških neslaganja u filozofiji vremena (usp. Zimmerman, 2008, 211):

(g) Postoje li objektivne razlike između onog prošlog, sadašnjeg i budućeg?

(h) Jesu li sadašnji događaji i stvari nekako više „stvarni“ od onih koji su potpuno u prošlosti ili budućnosti?

Prezentist bi načelno na oba pitanja odgovorio potvrdno, a eternalist bi na oba odgovorio negativno. Ipak, drugo pitanje se čini neobičnim. Prezentist ne bi rekao da je sadašnji događaj više stvaran od onog prošlog ili budućeg, nego je stvaran simpliciter. Ne bismo rekli da je „biti stvaran“ u tom smislu stvar stupnja: nešto je ili stvarno, ili nije. Ne može biti manje i više stvarno. Prošli događaj nije stvaran, a sadašnji jest stvaran. No, postoje verzije A teoretičara koje tvrde da prošli i budući objekti i događaji imaju neku vrstu postojanja, ali su lišeni svih interesantnih intrinzičnih svojstava za razliku od sadašnjih (Zimmerman, 2008, 215). Takve teorije se čine vrlo neplauzibilnima, ali ne namjeravamo ih u ovom radu posebno kritizirati.

Glavna je snaga A teorije u prezentističkom obliku duboka intuitivnost i slaganje s našim vremenskim iskustvima. Imamo vrlo jasnu koncepciju prolaznosti,

2 Za pojašnjenje leibnizovskog argumenta u modernom kontekstu usp. Pruss, 2009, 24-100. 
postajanja i nestajanja. Smatramo da su stvari prošlosti prošle, više nisu u redu stvarnosti. Budućnost je stvar anticipacije, nadanja, mogućnosti, a ne nešto što uviđamo postojećim kao što doživljavamo sadašnjost. Ako je vrijeme fenomen koji nastojimo objasniti, onda ima smisla da krenemo od onih osnovnih doživljaja koje povezujemo s vremenom. Prolaznost vremena čini se očitom, neizbježnom i sigurnom. Ako su to osnovna uvjerenja o vremenu, koja uglavnom svi dijelimo, teorija koja najelegantnije objašnjava naša uvjerenja trebala bi biti najbolja polazišna točka, a prezentizam potpuno odgovara opisu. U tom pogledu slažemo se s Zimmermanom kad kaže da je A teorija potpuno banalna:

»Jednostavno je razumljivo da su prošlost i budućnost manje stvarni od sadašnjosti; da je razlika između događaja i stvari koje postoje u sadašnjosti i onih koje ne postoj, mnogo dublja od razlike između događaja i stvari kojima sam u blizini i onih od kojih sam prostorno udaljen« (Zimmerman, 2008, 221).

U tom smislu A teorija, barem u prezentističkom obliku, sasvim podupire ta uvjerenja, a B teorija pruža suprotan pogled. Prima facie, u epistemološkom smislu, vrjednija je teorija koja može podržati naša osnovna vjerovanja o svijetu od one koja ih odbacuje. Ako su dane dvije vremenske teorije, recimo $\mathrm{V}^{1}$ i V², i ako $\mathrm{V}^{1}$ bolje objašnjava vrijeme pod vidikom naših osnovnih vjerovanja o svijetu od $\mathrm{V}^{2}$, onda $\mathrm{V}^{1}$ ima više epistemičke vrijednosti od $\mathrm{V}^{2}$. Ne treba ipak zaboraviti da bismo, ako imamo dobrih razloga odbaciti $V^{1}$, i nemamo snažnijih razloga protiv $\mathrm{V}^{2}$, ipak trebali prihvatiti $\mathrm{V}^{2}$. Iako se taj stav čini jednostavnim, stvar postaje komplicirana kad se sjetimo da filozofi različitih pristupa daju različitu važnost određenim aspektima spoznaje.

Ako smo racionalni epistemički realisti - a uvriježeni stav među prirodoznanstvenicima, i barem relativnoj većini epistemologa, epistemički je i metafizički realizam — to da smo prima facie opravdani u osnovnim vjerovanjima koja impliciraju A teoriju i dalje vrijedi. Ako imamo neko osnovno vjerovanje kao „Fido, pas mojeg pradjeda, više ne postoji“, prezentizam će slijediti inferencijalno iz tog osnovnog vjerovanja. Ključno je primijetiti kako upravo to mislimo kad kažemo da Fido više ne postoji, a ne mislimo da Fido zapravo još uvijek postoji, samo ranije od nas. Racionalni epistemički realist neće zahtijevati da su sva naša osnovna vjerovanja istinita — opravdanje koje odolijeva nesuvislim poništivačima dostatno je da se tim osnovnim vjerovanjima dodijeli pozitivan epistemički status. Ako bi se pojavili dobri razlozi za druga vjerovanja, ozbiljni poništivači našim osnovnim vjerovanjima, racionalni epistemički realist odbacio bi osnovna vjerovanja.

U svjetlu moderne znanosti, moguće je da su se takvi poništivači pojavili. Razlog velikoj popularizaciji B teorije u dvadesetom stoljeću pojava je specijalne teorije relativnosti (STR), u kojoj je Einstein odbacio neke uvriježene intuicije o vremenu i prostoru, a koje je klasična fizika njegovala još od Newtona. Budući da se teorija relativnosti pokazala kao jedna od najuspješnijih teorija u znanosti, a u svojoj najpopularnijoj interpretaciji pretpostavlja B teoretsku ontologiju, razvilo se snažno mišljenje da je A teorija time zapravo opovrgnuta. To je jamačno najjači prigovor protiv A teorije, pa ćemo u ovom radu pokušati umanjiti njegovu 
snagu. Drugi prigovor koji se najviše povezuje s A teorijom problem je istinitosti prošlih i budućih sudova. Smatramo da su ta dva prigovora zapravo najvažniji, iako nisu jedini. Ako u duhu epistemološkog realizma (i optimizma) pođemo od toga da je A teorija intuitivno epistemički opravdana — a mi to činimo - prigovori u prilog B teoriji pretendiraju na razinu bolje alternative, a ne izravnog opovrgavanja.

\subsection{Problem istinitosti prošlih i budućih sudova}

Problem istinitosti prošlih i budućih sudova redovito se ponavlja u modernim raspravama. Iako postoje različite teorije istine, klasična definicija i dalje uspijeva zadržati važnost i privlačnost. Istina je prema njoj adeqatio intellectus et rei, pretpostavlja korespondenciju uma i stvarnosti. Postoji nešto jako intuitivno u toj definiciji. Čini nam se prihvatljivim da je propozicija „Netko upravo pljačka banku u kućnom ogrtaču“ istinita ako netko doista pljačka banku u kućnom ogrtaču. Primijetimo da ta definicija uključuje dva područja i jednu relaciju. S jedne strane imamo um koji nešto tvrdi ili niječe, s druge strane imamo stvarnost, onu res koja može korespondirati onomu što um tvrdi ili niječe. Sama korespondencija je relacija koja osigurava spoznajno odgovaranje onog tvrđenog s onim na što se tvrdi. Ta relacija vrlo je zanimljiva jer transcendira ono subjektivno, umno, propozicijsko, i dotiče ono objektivno i činjenično. U primjeru s pljačkašem vidimo da je uvjet istinitosti suda zapravo res, odnosno pravi događaj pljačkanja banke.

No, što ako propozicija ne referira na nikakav postojeći objekt ili događaj? Uzmimo rečenicu „Svi goblini imaju loš smisao za humor“: je li ta rečenica istinita ili neistinita? Postoje različiti pristupi tomu problemu. Mogli bismo reći da je rečenica neistinita jer goblini ne postoje; ne postoji taj određeni res za koji tvrdimo da ima loš smisao za humor. S druge strane, možemo reći da je rečenica neodređena, nije zapravo ni istinita ni lažna. U kontekstu plurivalentnih logika, osim istinitih i neistinitih propozicija, sasvim je opravdano govoriti i o neodređenim propozicijama. Postoje i razne druge opcije (vidi: Lewis, 2001, 275). Bez obzira na njih, smatramo da očuvanje klasične definicije istine imamo samo u skladu s prvim odgovorom. Ako bismo odabrali bilo koju drugu strategiju, više ne bismo branili klasičnu teoriju istine, nego neku drugu. Uzmimo u obzir da su goblini u tom primjeru označitelji istinitosti, kao što je pljačkaš banke u ranijem primjeru označitelj istinitosti. Ako označitelj ne postoji, onda sud postaje neistinit. Mislimo da se tu lako može nazrijeti problem za prezentističkog A teoretičara. Prezentist vjeruje da samo sadašnji događaji postoje, a prošli i budući ne postoje. Ako prihvatimo korespondencijsku teoriju, izgleda da će svi sudovi o prošlosti i budućnosti biti lažni. Dakle, sud „Postojalo je Rimsko Carstvo“ postaje neistinit jednako kao i „Sutra će izići sunce“.

A teoretičaru nije teško naći odgovor na taj problem, iako će narav samog odgovora uvelike varirati o samom pristupu pojedinog A teoretičara. Prvi dio rješenja je pojmovna analiza res sastavnice korespondencijske definicije. Kad kažemo da sud treba korespondirati stvarnosti, ne mislimo da mora korespondirati nekoj trenutačno objektivno postojećoj stvari, ali moraju postojati neki uvjeti ili skup 
uvjeta koji su instancirani na neki način u sadašnjosti, a čine buduće i prošle sudove istinitima. Ti uvjeti mogu biti određene relacije ili svojstva koja su inherentna sadašnjim stanjima stvari. Recimo, osoba ima neko primitivno svojstvo ,imao pet godina“, i to svojstvo osigurava istinitost suda „Valentin je imao pet godina“.

Kad bi sve rečenice referirale na neke postojeće supstancije, ne bi bilo daljnjih problema. Ja, kao neka stvar u širem smislu, mogu instancirati neka svojstva, no što je sa stvarima koje ne postoje u sadašnjosti i nemaju nikakve sadašnje podloge za instancijaciju svojstava orijentiranih na prošlost? Što je sa sudom „Napoleon je posjedovao psa“"? Izlaz iz problema možemo uvidjeti u činjenici da nam nisu strogo potrebni objekti ili stvari kao podmeti instancijacije svojstava, nego nam je dovoljan sadašnji trenutak za instancijaciju tih svojstava (Miller, 2013, 335). Time problem ipak nije u potpunosti riješen. Postoje različiti načini na koji svojstva mogu biti instancirana. Primjerice, ako prihvatimo ontologiju diskretnih vremenskih trenutaka s primitivnim trajanjima, onda bismo imali nešto kao atome koji mogu biti podmetom instancijacije svojstava. S druge strane, vrijeme može biti kontinuirano nasuprot diskretnom. Primjerice, u aristotelovskom kontinuumu sami vremenski trenutci ne bi uopće imali trajanja — takav kontinuum se ne sastoji od diskretnih točaka. Za takve vrste kontinuiranih vremenskih ontologija, instancijacija svojstava bi svejedno mogla biti aktualna. Sam kontinuum bi mogao postati podmetom, iako, tada bi morali razgovarati u terminima kontinuiranih intervala, a ne trenutaka. Trenutci ne bi mogli biti podmet instancijaciji vremenskih svojstava jer ne postoji vrijeme kad se ti trenutci protežu u vremenu, oni su samo alati pojmovne razdiobe.

Problem, dakle, nije univerzalan, nego zahtijeva dublju analizu ontologije vremenskih trenutaka. Određene prezentističke ontologije mogu imati taj problem ovisno o podmetu na koji instanciraju temporalna svojstva. Moguće je čak i u kontekstu teoloških spekulacija govoriti o instancijaciji tih svojstava u božanskom umu, što bi maknulo bilo kakvu potrebu instancijacije svojstava u vrijeme ili trenutke. Čak i bez teološkog konteksta, propozicijske teorije značenja - u slozi s korespondencijskim teorijama istinitosti — od Fregea i Russella nisu izgubile svoju privlačnost, a one bez velikih skrupula računaju s propozicijama kao vječnim i neprostornim intencionalnim entitetima (Lycan, 2011, 96-97).

Štogod bio slučaj, vidimo da se sam problem može riješiti ako uvedemo primitivna vremenska svojstva koja bi dala upravo tu res koja nam treba za korespondencijsku teoriju istine. Iako to nije kontroverzno, treba uzeti u obzir da samim time cijeli posao nije riješen. Svaki prezentist mora se nositi s tim problemom i ovisno o svojem shvaćanju osnovne strukture vremena odrediti podmet instancijacije tih svojstava.

\subsection{Problem nekompatibilnosti sa specijalnom teorijom relativnosti}

Čini se da je najteži prigovor A teoriji vremena i, povijesno gledano, glavni razlog bacanja teške sumnje na A teoriju, specijalna teorija relativnosti. Pod najtežom kritikom je metafizika prezentizma: nakon Einsteina gotovo je bespredmetno govoriti o apsolutnoj istovremenosti i klasičnim konceptima vremena i 
prostora. Koji trenutak je sadašnji različito je za različite promatrače iz različitih uniformnih sustava gibanja. Hermann Minkowski je famozno ustvrdio: »Odsada, prostor za sebe i vrijeme za sebe osuđeni su na propast u puke sjene, samo će vrsta jedinstva tog dvoje sačuvati neovisnu stvarnost « (Minkowski, 2015, 75).

Empirijske potvrde i uspješnost teorije osigurale su njezin pozitivan epistemički status, pa se prihvaćanje njezinih teorijskih okvira činilo neizbježnim. Ipak, taj pogled je pojednostavljen i ne uzima važne stvari u obzir. Kao prvo, na sasvim općenitoj razini možemo uočiti dvije komponente fizikalnih teorija: matematički formalizam i fizikalnu interpretaciju tog formalizma (Craig, 2008, 11). Iako fizikalne teorije mogu imati isti matematički formalizam i isti empirijski sadržaj, interpretacije mogu biti sasvim različite. Fizikalne teorije mogu biti i donekle različite u svojim formalizmima, ali ipak zadržati isto relevantno tijelo formalizacija. Empirijski sadržaj odnosi se na različite eksperimente i provjere. Isti eksperimenti mogu se tumačiti na različite načine, ovisno već o formalizacijskom, ali i širem filozofskom okviru. Interpretacije određene teorije, ovisno o polju o kojem govorimo, pretpostavljaju različite epistemičke i ontološke pretpostavke koje obično nisu izvedene na vidjelo. Primjerice, Einsteinov pristup problemu prostora i vremena vidljivo je obojen empirističkim i verifikacionističkim pretpostavkama te kulminira u operacionalnoj definiciji vremena u početnoj verziji specijalne teorije relativnosti. Zanimljivo, Einstein upućuje kritiku filozofima:

»Uvjeren sam da su filozofi imali štetan utjecaj na napredak znanstvene misli i to u odmicanju određenih fundamentalnih pojmova iz domene empiricizma, gdje su pod našom kontrolom, u neopipljive visine onog a priori.« (Einstein, 2007b, 266)

Einstein tu misli na vrijeme i prostor, koji bi se trebali definirati samo s obzirom na ono što možemo nekako izmjeriti. Uzevši u obzir tu pretpostavku, ne bi nas trebala iznenaditi Einsteinova operacionalna definicija vremena. Njegova definicija vremena proizlazi iz definicije simultanosti, a simultanost dobiva sinkronizacijom satova pomoću svjetlosnih signala:

»Neka svjetlosni signal krene u 'A vremenu' tA od A do B, i neka u 'B vremenu' tB bude reflektiran od B prema A, i neka stigne do A u 'A vremenu' t'A. U skladu s definicijom, dva su sata sinkronizirana ako je tB - tA = t’A - tB.«(Einstein, 2007a, 7)

Usprkos tomu, vidimo da ta definicija jednostavno pretpostavlja da apsolutni prostor ne postoji: isključen je u samom početku. Jer, kad bi bio slučaj da se A i B apsolutno kreću, bez obzira na to što su relativno jedan od drugoga u mirovanju, put od A do B ne bi bio jednak putu od B do A (Craig i Smith, 2008, 3). Takva je definicija radikalno drukčija od Newtonove, stoga predstavlja potpuno drugi pogled na vrijeme i prostor. Apsolutno vrijeme kod Newtona nema nikakve povezanosti sa satovima i brzinom svjetlosti. Tu je Einstein zapravo samo radikalno redefinirao termine i to kako bismo o vremenu mogli razgovarati sa strogim fizikalnim značenjem. Važno je zato primijetiti da je sam kontekst govora o vremenu u STR specijalizirani, operacionalno definirani kontekst koji nikako ne ispunjava cijelo područje filozofskog razgovora o vremenu. Uzevši da su zakoni prirode isti u svim referentnim sustavima i da je brzina svjetlosti konstantna, izvodimo 
različite zaključke svojstvene klasičnoj teoriji relativnosti. Prvo, uviđamo da je vrijeme kad se dogodio neki događaj relativan referentnom sustavu iz kojeg gledamo: za nekog vrijeme teče sporije, a za nekog brže. Drugo, ne postoji nešto kao apsolutna istodobnost, jer su neka dva događaja koja prepoznajemo istodobnost u jednom sustavu zapravo moguće neistodobna u drugom sustavu. Ne postoji neki privilegirani referentni sustav koji bi odredio jesu li dva događaja uistinu istodobna ili ne.

Rekavši to, ne vidimo u početnoj Einstenovoj formulaciji STR-a direktnu nekompatibilnost s A teorijom. Ona je u svojoj izvornoj verziji nekompatibilna samo s Newtonovim konceptima apsolutnog vremena i prostora. U filozofskoj se zajednici prepoznaje problematičnom (za A teoriju) verzija koju možemo zvati Minkowskijevom interpretacijom STR-a. Minkowski je zapravo napravio geometrijsku reprezentaciju STR-a, prostor-vrijeme je počeo uzimati u snažnom ontološkom smislu kao adekvatan opis svijeta. Referentni sustavi, invarijantna brzina svjetlosti, relativno gibanje ili stajanje, izgubili su svoju centralnost, a središnja struktura postao je poznati svjetlosni čunj koji određuje geometrijska svojstva prostor-vremena (Craig, 2008, 13). Dok Einsteinova interpretacija dopušta metafiziku temporalnog postajanja i nestajanja, Minkowskijeva nas veže na neobičan zaključak nepostojanja prave razlike između stvarnosti sadašnjosti, prošlosti i budućnosti: ne postoji apsolutno postajanje i nestajanje, svaki trenutak u vremenu je jednako stvaran (Craig, 2008, 27). To je uzrokovalo pojavu raznih teorija vremena koje ignoriraju samu pojavu vremenskog prolaska i smatraju dijelove vremena jednako stvarnima (Bigelow, 2013, 159). Ta verzija STR-a povlači B teoretsku ontologiju i nekompatibilna je s prezentizmom i tezom o početku svemira te predstavlja najbolji razlog prihvaćanja eternalizma.

Postoje dva općenita načina kako možemo odgovoriti na taj problem. Prvo, moguće je umjesto Minkowskijeve interpretacije izabrati neku verziju Lorentzove interpretacije STR-a. Iako je marginalizirana u današnjoj znanosti, neki je fizičari, poput H. E. Ivesa, Geoffreya Buildera i S. J. Prokhovnika, brane. Postoji više različitih modela zamjene koji bi poslužili kao označitelji privilegiranog sustava na temelju kojeg možemo definirati apsolutnu istodobnost i tako je vratiti natrag u život zajedno s objektivnosti vremena (Craig, 2008, 29). Često se u tom kontekstu čuje prigovor da ta interpretacija vraća neki oblik etera u život, a koncept etera smo davno nadišli. No, riječ eter se u tom kontekstu koristi samo kao skraćena riječ za privilegirani inercijski sustav, nije potrebno da eter ima nekakva posebna svojstva kao onaj koji su pokušavali detektirati Michelson i Morley. Jedan od modela koji zamjenjuje eter je, primjerice, model pozadinske mikrovalne radijacije. Čak i notorni B teoretičar kao što je J. J. C. Smart, priznaje da:

»iako specijalna teorija relativnosti ne određuje privilegirani inercijski sustav, ne isključuje mogućnost da neki takav privilegirani sustav biva određen izvan same teorije. Možemo pretpostaviti da bismo trebali uzeti u obzir lokalno privilegirani sustav u kojem je pozadinska kozmička radijacija jednaka u svim smjerovima.« (Smart, 2008, 233)

Privilegiranost određenog inercijskog sustava nije neka radikalna i čudna ideja, može se nazrijeti i iz modela izvedenog iz kvantne elektrodinamike. Prije se 
smatralo da elektromagnetska energija putuje kroz prazni vakuum, a kasnije se prepoznalo da vakuum nije prazan, nego je sjedište fluktuirajućih elektromagnetskih polja. P. Dirac, koji je, uostalom, predvodio napredak relativističke kvantne elektrodinamike, uzimao je idealizirano stanje kvantnog vakuuma kao zamjenu za eter (Craig, 2008, 29). Lorentzova interpretacija, iako ima drukčije tumačenje matematičkog formalizma i nekih empirijskih eksperimenata, u svojoj biti nije relativistička. Ona zadržava koncepte naslijeđene od Newtona i osigurava opravdanost prezentističke teorije vremena. Vjerojatno je da bismo mogli opravdati Lorentzovu interpretaciju na temelju same znanosti jer se ne čini eksplanatorno inferiornom Minkowskievoj, ali i na temelju plauzibilnijeg filozofskog temelja.

Zanimljivo je napomenuti da su Lois De Broglie i David Bohm izradili tumačenje kvantne mehanike koje implicira da postoji apsolutna simultanost, iako je njihovo rješenje bilo široko ignorirano, dok J. S. Bell nije napisao eseje o njima (Craig i Smith, 2008, 8). Poanta je da, iako Minkowskijev pogled na vrijeme može biti instrumentalno opravdan u određenim okolnostima, ničim nas ne obvezuje na početno privilegiranje geometrijskog pogleda na vrijeme i njegovih ontoloških implikacija. Dapače, možemo uvidjeti vraćanje apsolutne simultanosti koju odbacuje njegova verzija STR-a u sasvim drugim kontekstima, opet za različite potrebe drugih teorija. Dakle, STR nikad nije nedvosmisleno dokazala kako je vrijeme takvo i takvo. Najbolje je što možemo tvrditi to da je operacionalno definirano vrijeme $\mathrm{u}$ određenim kontekstima fizikalnih interpretacija prikazano ovako ili onako. Odnosno, možemo prikazati kako će se odnositi naše mjere vremena jedne prema drugima, no ne nužno i samo vrijeme koje može biti shvaćeno na različite načine ovisno o pretpostavkama.

Drugi je način odgovaranja na problem tvrdnja da A teorija ne treba zapravo nezaobilazno prihvaćanje neke verzije Lorentzove interpretacije STR-a. Smatramo da je upravo na tom tragu ranije navedena primjedba J. J. C. Smarta, ali i rješenje D. Zimmermana (Zimmerman, 2008, 219). Minkowskijeva interpretacija STR-a ne razlučuje bitno između sadašnjosti, prošlosti i budućnosti, ali to samo po sebi ne znači da se razlika ne može povući. Točnije bi bilo reći da fizika ne može odrediti razliku ili da nije relevantno za naš matematički model, no to ne znači da de facto ne postoji razlika. Fizika se bavi svojim specijaliziranim predmetom i zaobilazi podjele koje su u filozofiji vrlo važne. Razlika između čovjeka i slona nije vidljiva na samoj razini elementarnih čestica, ali razlika de facto postoji i vrlo je važna, samo ne za fiziku. Sadašnji bi trenutak tako mogao u načelu biti privilegiran, iako to ne bi bilo vidljivo iz same teorije.

Rekli bismo da je problem nekompatibilnosti A teorije vremena sa STR-om zapravo podosta upitan i zahtijeva veću interdisciplinarnu razradu filozofa i fizičara. Kao prvo, vidimo da postoje različiti načini kako možemo interpretirati samu teoriju, a i te interpretacije imaju različita tumačenja ovisno o različitim fizičarima i pristupima. Iako je trenutačno popularna Minkowskijeva verzija STRa, to nije dovoljno za odbacivanje A teorije. Sve dok možemo dati plauzibilan slučaj neke druge interpretacije STR-a koja bi bila koherentna s A teorijskim konceptima, nema potrebe za prihvaćanjem isključivo jednog pogleda na stvar. 
Razlog zašto je bolje održati A teoriju u filozofskom smislu očituje se u izbjegavanju velikih filozofskih problema i kontraintuitivnosti koje proizlaze iz B teorije (Craig, 2008, 27). Možda je čak i moguće zadržati Minkowskijev pristup STR-u, ali odustati od hiperrealističkih tumačenja matematičkog formalizma: rezultati dobiveni iz formalnih aksiomatskih sustava vrlo su korisno oruđe za specijalizirani govor o svijetu, ali oruđe za govor o svijetu i svijet ne smiju biti grubo poistovjećeni. To, doduše, ostavljamo za buduću razradu. Tako da, uzevši razmatranje u obzir, ne možemo još tvrditi da postoje empirijski ili snažni fizikalni dokazi koji bi opovrgnuli A teoriju. Naš pogled na vrijeme bit će mnogo više podložan našim interpretacijama različitih apstraktnih fizikalnih modela i generalnim epistemičkim načelima. Mislimo da je to dovoljno da se prigovor iz specijalne teorije relativnosti oslabi u relevantnoj mjeri.

\section{Zaključak}

Teza da svemir ima početak snažno je opravdana aposteriornim razlozima. Uvriježeni kozmološki model implicira sliku svemira koji je imao početak, iako iz samog fizikalnog modela nije jasno treba li taj početak interpretirati kroz A ili B vremensku ontologiju. Argumentirali smo da je A teorija daleko intuitivnija i ima znatno više početnog opravdanja od B teorije. Potrebni su posebni poništivači za pobijanje A teorije, a oni su utjelovljeni u dva najjača prigovora: problem istinitosti prošlih i budućih sudova te problem nekompatibilnosti sa specijalnom teorijom relativnosti.

Prvi prigovor je riješen kad A teoretičar nađe prikladan podmet za instancijaciju temporalnih svojstava, za što ima različitih rješenja, ovisno o shvaćanju vremenskih trenutaka. Drugi prigovor je, strogo govoreći, neistinit. Nije istina da je A teorija nekompatibilna sa specijalnom teorijom relativnosti simpliciter, nego je nekompatibilna s Minkowskijevom interpetacijom te teorije. To je problematično, jer ona predstavlja prevladavajuću interpretaciju u fizikalnoj zajednici. Problem se može riješiti na tri načina. Najradikalniji je način prihvaćanje lorentzovske interpretacije STR-a, koja nije toliko popularna, ali ima modernih branitelja u fizici. Drugi je način uvođenje ekstrateorijskih odredbi STR-a: možda fizika ne prepoznaje razlike postojanja prošlosti, sadašnjosti i budućnosti, ali to ne znači da se razlika ne može povući izvan same teorije. Treći je način odustajanje od hiperrealističke interpretacije matematičkog formalizma STR-a, koja bi ostavila mjesta A teorijskoj ontologiji, ali je to ideja koja je u začetku i nismo je ovdje uspjeli posebno braniti. Bilo koje od tih rješenja omogućilo bi da u punom smislu tvrdimo da je svemir počeo postojati i prihvatimo klasične metafizičke pretpostavke nastajanja kao što je ex nihilo nihil fit. Valja spomenuti da je filozofija vremena prijeporno područje i još uvijek izostaje opći konsenzus oko tog pitanja, što također služi relativizaciji samog prigovora iz tabora B teorija. Javljaju se razne hibridne teorije koje pokušavaju spojiti B teorijsku ontologiju s A teorijskim nastajanjem, što je svakako pogodno za tezu o početku svemira i argumente koji se na nju oslanjaju. 


\section{Literatura:}

Bigelow, John (2013). The Emergence of a New Family of Theories of time. U: Heather Dyke; Adrian Bardon (ur.), Companion to the Philosophy of Time (str. 151-156). Oxford: Wiley-Blackwell.

Borde, Arvind; Guth, Alan W.; Vilenkin, Alexander (2003). Inflationary Spacetimes Are Incomplete in Past Directions. Physical Review Letters, 15(90). URL: https://arxiv.org/ abs/gr-qc/0110012 (12.09.2017.)

Craig, William L. (1994). A Response to Grünbaum on Creation and Big Bang Cosmology. Philosophia Naturalis, 31, 237-249. URL: http://www.reasonablefaith.org/aresponse-to-grunbaum-on-creation-and-big-bang-cosmology\#ixzz4GBdbCLGz (24.7.2016).

Craig, William L. (2000). The Tensed Theory of Time: A Critical Examination. Dordrecht: Springer.

Craig, William L. (2008). The Metaphysics of Special Relativity: Three Views. U: William Lane Craig i Quentin Smith (ur.), Einstein, Relativity and Absolute Simultaneity (str. 11-49). New York: Routledge.

Craig, William L.; Smith, Quentin (2008). Introduction. U: William Lane Craig i Quentin Smith (ur.), Einstein, Relativity and Absolute Simultaneity (str. 1-10). New York: Routledge.

Craig, William L.; Sinclair, James D. (2009). The Kalam Cosmological Argument. U: William Lane Craig i J. P. Moreland (ur.), The Blackwell Companion to Natural Theology (str. 101-201). Oxford: Wiley-Blackwell.

Einstein, Albert (2007a). On the Electrodynamics of Moving Bodies. U: Stephen Hawking (ur.), A Stubbornly Persistent Illusion: The Essential Scientific Works of Albert Einstein (str. 4-31). Philadelphia: Running Press.

Einstein, Albert (2007b). The Meaning of Relativity. U: Stephen Hawking (ur.), A Stubbornly Persistent Illusion: The Essential Scientific Works of Albert Einstein (str. 265-282). Philadelphia: Running Press.

Hawking, Stephen W. (2007). The Theory of Everything: The Origin and Fate of The Universe. Beverly Hills: Phoenix Books.

Lewis, David (2001). Forget about the 'Correspondence Theory of Truth'. Analysis, 61(4), 275-280.

Liddle, Andrew (2003). Introduction to Modern Cosmology. Chichester: Wiley.

Lycan, William G. (2011). Filozofija jezika: Suvremeni uvod. Zagreb: Hrvatski studiji.

Markosian, Ned (2014). Time. U: The Stanford Encyclopedia of Philosophy (proljetno izdanje 2014.). URL: http://plato.stanford.edu/entries/time/ (05.03.2016.)

McTaggart, John E. (1908). The Unreality of Time. Mind, 17(68), 457-474.

Miller, Kristie (2013). Presentism, Eternalism, and the Growing Block. U: Heather Dyke i Adrian Bardon (ur.), Companion to the Philosophy of Time (str. 345-364). Oxford: Wiley-Blackwell.

Minkowski, Hermann (2015). Space and Time. U: The Principle of Relativity. Mansfield: Martino Publishing.

Mithani, Audrey; Vilenkin, Alexander (2011). Did the universe have a begininng. U: ArXiv.org. URL: http://arxiv.org/pdf/1204.4658v1.pdf (23.07.2016.)

Mozersky, Joshua M. (2013). The B-Theory in the Twentieth Century. U: Heather Dyke i Adrian Bardon (ur.), Companion to the Philosophy of Time (str. 167-182). Oxford: Wiley-Blackwell. 
Paar, Vladimir (2011). O komplementarnosti znanosti i vjere. U: Zoran Primorac (ur.), Suvremena znanost i vjera (str. 17-36). Mostar: Fakultet prirodoslovno-matematičkih i odgojnih znanosti Sveučilišta u Mostaru.

Petković, Tomislav (2006). Uvod u modernu kozmologiju i filozofiju. Zagreb: Element.

Reichenbach, Bruce (2016). Cosmological Argument. U: The Stanford Encyclopedia of Philosophy (zimsko izdanje 2016). URL: https://plato.stanford.edu/archives/win2016/ entries/cosmological-argument/ (01.10.2017.)

Smart, John J. C. (2008). The Tenseless Theory of Time. U: Theodore Sider, John Hawthorne i Dean W. Zimmerman (ur.), Contemporary Debates in Metaphysics (str. 226238). Oxford: Blackwell Publishing.

Zimmerman, Dean (2008). The Priviledged Present: Defending an 'A-Theory' of Time. U: Theodore Sider, John Hawthorne i Dean W. Zimmerman (ur.), Contemporary Debates in Metaphysics (str. 211-225). Oxford: Blackwell Publishing.

The A-Theory of Time and the Beginning of the Universe

Valentin Stuhne*, Dalibor Renić**

\section{Summary}

The question about the beginning of the universe is crucial in philosophy in view of certain cosmological arguments for God's existence (notably the Kalām cosmological argument), but it is also interesting in itself. This article defends the position that an interpretation of the beginning of the universe in terms of $A$-theoretical ontology is justified, as opposed to the B-theory. The two strongest objections to the Atheory are the problems of veracity of arguments on past and future events and the incompatibility of the A-theory with the Special Theory of Relativity. We argue that the first objection is resolved upon the A-theorist's finding a suitable subject for the instantiation of temporal properties. As for the second objection, it is not true that the A-theory is incompatible with the Special Theory of Relativity simpliciter: it is only incompatible with Minkowski's interpretation. We propose a few steps towards avoiding this interpretation.

Key words: philosophy of time, beginning of the universe, cosmological argument, standard cosmological model, A-theory of time, B-theory of time

* Valentin Stuhne, mag. phil., Faculty of Catholic Theology, University of Innsbruck. Address: Karl-Rahner-Platz 1, Innsbruck, Austria. E-mail: valentin.stuhne@student.uibk.ac.at

** Dalibor Renić, Ph.D., Assistant Professor, Faculty of Philosophy and Religious Studies, University of Zagreb. Address: Jordanovac 110, 10000 Zagreb, Croatia. E-mail: drenic@ffrz.hr 